\title{
Ultrasound-Assisted Treatment of Coconut Water Samples for Potentiometric Stripping Determination of Zinc
}

\author{
Rodrigo A. A. Munoz, Matias Kolbe, Rita C. Siloto, Pedro V. Oliveira and Lucio Angnes* \\ Instituto de Química, Universidade de São Paulo, Av. Prof. Lineu Prestes, 748, 05508-900 São Paulo-SP, Brazil
}

\begin{abstract}
Este trabalho descreve a utilização da análise por redissolução potenciométrica (PSA) sobre eletrodos de filme de mercúrio para a determinação de zinco em água de coco. Foi desenvolvida metodologia para o tratamento de tais amostras por ultra-som, otimizada para a determinação de zinco total por PSA. Um mililitro de amostra foi tratado com $2 \mathrm{~mL}$ da mistura 1:1 (v/v) de $\mathrm{HCl}$ concentrado e $\mathrm{H}_{2} \mathrm{O}_{2}(30 \% \mathrm{~m} / \mathrm{v})$ dentro de frascos fechados $(4 \mathrm{~mL})$ em um banho ultrassônico seguido de uma etapa de aquecimento em banho-maria por $15 \mathrm{~min}$. Esta metodologia foi otimizada para a determinação de zinco total e foi validada através de análise direta das amostras por espectrometria de absorção atômica com forno de grafite (GFAAS). O limite de detecção obtido pelo método proposto por PSA foi de $1.35 \mu \mathrm{g} \mathrm{L}^{-1}$ (aplicando $45 \mathrm{~s}$ de pré-concentração). Tentativas para quantificar cobre nas mesmas amostras mostraram que o conteúdo deste metal é menor que o limite de detecção de ambas as técnicas, GFAAS e PSA $\left(0.030 \mu \mathrm{g} \mathrm{L}^{-1}\right.$ depois de $600 \mathrm{~s}$ de pré-concentração) com eletrodos de ouro.
\end{abstract}

This work describes the application of potentiometric stripping analysis (PSA) at mercury film electrodes for zinc determination in coconut water. A sample ultrasound-assisted treatment was developed and optimised for the total zinc determination by PSA. One milliliter of sample was treated with $2 \mathrm{~mL}$ of $1: 1(\mathrm{v} / \mathrm{v})$ concentrated $\mathrm{HCl}$ and $\mathrm{H}_{2} \mathrm{O}_{2}(30 \% \mathrm{~m} / \mathrm{v})$ mixture in closed (4 $\mathrm{mL}$ ) vessels under sonication (in ultrasonic bath), followed by a thermal step (in a boiling bath, for $15 \mathrm{~min}$ ). This methodology was optimised for total zinc determination and was validated by graphite furnace atomic absorption spectrometry (GFAAS) analysis utilizing the sample without any treatment. The limit of detection obtained by the proposed PSA method was $1.35 \mu \mathrm{g} \mathrm{L}^{-1}$ (applying $45 \mathrm{~s}$ of preconcentration). Attempts to evaluate the amount of copper in the same sample show that the content of this metal is lower than the detection limits of both techniques, GFAAS and PSA $\left(0.030 \mu \mathrm{g} \mathrm{L} \mathrm{L}^{-1}\right.$ after $600 \mathrm{~s}$ of preconcentration) at gold film electrodes.

Keywords: potentiometric stripping analysis, zinc, copper, coconut water, ultrasound-assisted treatment, ultrasonic bath

\section{Introduction}

Coconut water is a common refreshing drink and has been used as an excellent isotonic in Brazil and other tropical countries. ${ }^{1}$ Extracted from the coconut endosperm (Cocos nucifera), coconut water has several applications, such as the preservation of sheep preantral follicles in $s i t u,{ }^{2}$ the replacement of the high cost total parenteral nutrition solutions ${ }^{3}$ and oral rehydration fluid for gastric and intestinal diseases. ${ }^{4}$

Due to this increasing interest on applications of coconut water, more recent contribution for the better understanding of its composition has been reported. ${ }^{5,6}$

*e-mail: luangnes@iq.usp.br
Santoso et $a l .{ }^{6}$ described the presence of vitamins, sugar, organic acids, fatty acids, amino acids, fibers, and minerals in coconut (Cocos nucifera). Cytokinins were identified and determined using micellar electrokinetic capillary chromatography after preconcentration by solid-phase extraction. ${ }^{7}$ Even contaminant species must be considered in the complex composition of coconut water since pesticide residues were detected recently. ${ }^{8}$

The consumption of coconut water has increased in Brazil. Therefore, analytical methods were developed in order to monitor and evaluate the chemical composition of this product. ${ }^{9}$ Elemental techniques have been applied for minerals monitoring in the Brazilian coconut water, such as, inductively coupled plasma optical emission 
spectrometry (ICP-OES) for $\mathrm{Mn}, \mathrm{Fe}, \mathrm{Cu}$ and $\mathrm{Zn},{ }^{9}$ for $\mathrm{Ca}$, $\mathrm{Mg}, \mathrm{Mn}, \mathrm{Fe}, \mathrm{Zn}$ and $\mathrm{Cu}$ determinations, ${ }^{10}$ and graphite furnace atomic absorption spectrometry (GFAAS) for selenium. ${ }^{11,12}$ Capillary electrophoresis was applied for the separation and detection (contactless conductivity) of anions $\left(\mathrm{Cl}^{-}, \mathrm{SO}_{4}{ }^{2-}, \mathrm{PO}_{4}^{3-}\right.$, malate and ascorbate), cations $\left(\mathrm{Na}^{+}, \mathrm{K}^{+}, \mathrm{Ca}^{+}\right.$, and $\mathrm{Mg}^{2+}$ ) and sugars (fructose, glucose, and sucrose) in coconut water samples. ${ }^{13}$ Direct chloride determination via flow injection analysis with potentiometric detection without sample pre-treatment was described for milk and coconut water samples. ${ }^{14}$

Despite electrochemical techniques are well documented to trace metal determination due to their high selectivity and sensitivity, minerals determination in coconut water samples has just been carried out by spectroscopic methods, such as ICP-OES and GFAAS. Probably, the lack of electroanalytical methods for coconut water analysis is due to the complex composition of the sample containing a large variety of organic molecules, ${ }^{6}$ which adsorb on the working electrode surface during the electrodeposition step. Potentiometric stripping analysis (PSA) is considered the electroanalytical technique less susceptible to interferences of adsorption on the electrode surface. ${ }^{15-18}$ Exploring this advantage, the analysis of complex matrix samples, such as blood and serum, was reported without any sample preparation. ${ }^{19}$ The samples were just diluted in an adequate electrolyte prior the standard addition analysis.

In this work, we evaluated the use of PSA for zinc determination in the matrix of coconut water samples. Zinc is a micronutrient present and little information is known about how this metal is found in this complex fluid. This nutrient plays a fundamental role in the regulation of immune functions in humans. Coconut water is an important source of zinc and the effort to quantify zinc directly in this sample was affected by strong adsorption of organic matter on the mercury film electrode, so that a previous treatment of the sample was essential.

To overcome the sample matrix interferences and explore the possible advantages offered by electroanalytical stripping techniques such as the low-cost and portable instrumentation, the ease of miniaturization, and the remarkable sensitivity and selectivity for trace metal determinations, ${ }^{20}$ a new and efficient procedure of sample preparation was developed for zinc determination in coconut water. The samples were treated in the presence of concentrated $\mathrm{HCl}$ and $\mathrm{H}_{2} \mathrm{O}_{2}$ at closed vessels under sonication followed by a boiling water heating step. Previously, ultrasonic baths have been successfully applied for the preparation of environmental, ${ }^{21-26}$ biological ${ }^{27,28}$ and food samples ${ }^{29,30}$ and now we propose the combination of ultrasound followed by heating $\left(\sim 100{ }^{\circ} \mathrm{C}\right)$ for coconut water samples treatment for PSA zinc determination.

\section{Experimental}

\section{Reagents, samples and materials}

Zinc and copper reference solutions were prepared from Titrisol standard solutions (Merck, Darmstadt, Germany). Analytical grade concentrated hydrochloric $(30 \%, \mathrm{~m} / \mathrm{v})$ and nitric acids $(65 \%, \mathrm{~m} / \mathrm{v})$, hydrogen peroxide $(30 \%, \mathrm{~m} / \mathrm{v})$, sodium chloride, sodium hydroxide, and ammonium monohydrogen phosphate (Merck, Darmstadt, Germany) were used without further purification. Triton X-100 was purchased from Aldrich (Aldrich, Milwaukee, Wisconsin). Deionized water $(18 \mathrm{M} \Omega \mathrm{cm}$ ) obtained from a Milli-Q water purification system (Millipore, Bedford, MA, USA) was used to prepare all solutions and samples.

Coconut water samples were extracted directly from coconut fruit through sterilized and decontaminated syringes and were stocked at polyethylene vessels at $10^{\circ} \mathrm{C}$. Packaged coconut water samples were maintained in the same conditions of storage. Both kinds of sample were acquired in local markets of Sao Paulo city. Due to the diversity of coconut water composition, samples of 40 coconut waters were utilized for the optimization of PSA parameters, as sample standardization.

Aiming to evaluate the amount of zinc in different portions of coconut water by PSA, four different portion of a sample were separated. Two different portions were obtained by filtration through Millipore filters for $500 \mathrm{kDa}$ and $200 \mathrm{kDa}$ applying vacuum filtration. Aliquots containing molecules smaller than $50 \mathrm{kDa}$ and $5 \mathrm{kDa}$ were separated applying ultra-centrifugation.

\section{Instrumentation}

Electrochemical measurements were performed with an Autolab PGSTAT20 potentiostat (EcoChemie, Utrecht, Netherlands). The Autolab software makes the derivative calculation and presents directly the $\mathrm{d} t / \mathrm{d} E$ vs. E plot. A Microsonic SX-20 (Eurosonic, Brazil) ultrasonic bath operating at $20 \mathrm{kHz}$ was utilized to accelerate the decomposition procedure for total zinc determination. A ZEEnit $^{\circledR} 60$ model (AnalytikjenaAG, Jena, Germany) graphite furnace atomic absorption spectrometer (GFAAS) equipped with an inverse and transversal Zeeman-effect background corrector, pyrolytically coated transverseheated graphite atomizer was employed for zinc determination to compare with the electroanalytical results. The spectrometer was operated with a hollow 
cathode lamp for zinc using $213.9 \mathrm{~nm}$ as wavelength. All measurements were based on integrated absorbance values controlled by Windows NT ${ }^{\circledR}$ software. Argon $99.998 \%$ (v/v) (Air Liquide Brasil, São Paulo, Brazil) was used as purge gas.

\section{Electrochemical cell and electrodes}

A homemade Plexiglas cell (3 $\mathrm{mL})$ was used for the electrochemical measurements. A thin mercury film plated onto a glassy carbon electrode was used for zinc determinations. The mercury thin-layer film was obtained applying $-700 \mathrm{mV}$ for 5 minutes in a solution containing 1 mmol L-1 mercury(II) and $100 \mathrm{mmol} \mathrm{L}^{-1} \mathrm{HCl}$ under stirring. The reference and auxiliary electrodes were a miniaturized $\mathrm{Ag} / \mathrm{AgCl}_{\text {(sat) }}{ }^{31}$ and a platinum wire, respectively.

Gold film electrodes obtained from recordable compact discs, which were developed by our group, ${ }^{32}$ were utilized for copper determinations.

\section{Sample preparation}

A mixture $1: 1(\mathrm{v} / \mathrm{v})$ of concentrated $\mathrm{HCl}$ and $\mathrm{H}_{2} \mathrm{O}_{2}$ $(30 \%)$ was applied for the decomposition of organic matter in coconut water. The vessels containing $1 \mathrm{~mL}$ of sample and $2 \mathrm{~mL}$ of reagent mixture were tightly closed and transferred to an ultrasonic bath, sonicated for 15 minutes, and then put into a boiling water bath at $100{ }^{\circ} \mathrm{C}$. After 8 minutes under boiling water, the pressure inside the flasks was alleviated (by unscrewing the cap of the tubes). The samples were maintained in the boiling water bath for more 7 minutes to eliminate the excess of hydrogen peroxide, which may interfere on PSA measurements. Three different sample-reagent mixture were evaluated. The total time required for the complete procedure here presented (just $\sim 30$ minutes) compares favorable with other conventional systems.

\section{PSA of zinc and copper after sample preparation}

For zinc, aliquots of $300 \mu \mathrm{L}$ of sample were transferred to the electrochemical cell. Over this solution, the same volume of $2 \mathrm{~mol} \mathrm{~L}^{-1} \mathrm{NaOH}$ was added to neutralize the strong acid remaining from the previous treatment. Over this solution, $800 \mu \mathrm{L}$ of buffered solution $\left(0.2 \mathrm{~mol} \mathrm{~L}^{-1}\right.$ acetic acid +0.2 mol L $^{-1}$ sodium acetate) was introduced. The final $\mathrm{pH}$ of the solution in the cell was approximately 4.7. Dissolved oxygen in solutions were used as the oxidant agent to re-oxidize the metal electrodeposited on the working electrode surface during the stripping step. Table 1 presents the optimized PSA parameters.
For copper determination the treated samples were just diluted ten times (the dilution is necessary due to the excess of $\mathrm{Cl}^{-}$after the sample treatment, which facilitates the oxidation of the gold electrode) with deionised water in the electrochemical cell before measurement. In this case, a constant current was applied in the stripping step to re-oxidize the copper electrodeposited on the gold electrode. The standard addition method was applied for all analyses.

Table 1. PSA parameters for zinc and copper determination in coconut water

\begin{tabular}{lcc}
\hline PSA parameters & $\mathrm{Zn}$ & $\mathrm{Cu}$ \\
\hline Conditioning potential/(mV) & -600 & +650 \\
Conditioning time/(s) & 20 & 20 \\
Deposition potential/(mV) & -1400 & 0 \\
Deposition time/(s) & $30-45$ & 600 \\
Equilibrating time/(s) & 14 & 14 \\
Potential limit/(mV) & -600 & +650 \\
\hline
\end{tabular}

\section{GFAAS determination}

The GFAAS heating program for zinc and copper determination is presented in Table 2. In this study, the samples were diluted 100 times in $0.14 \mathrm{~mol} \mathrm{~L}^{-1}$ nitric acid solution for zinc. On the other hand, the samples were shortly diluted $(0.95: 1 \mathrm{v} / \mathrm{v})$ when copper was determined due to its very low concentration. Due to the excess of organic matter in this case, it was necessary the addition of $0.1 \% \mathrm{v} / \mathrm{v} \mathrm{HNO}_{3}$ and $0.05 \% \mathrm{~m} / \mathrm{v}$ Triton X-100 to avoid the formation of organic deposits over the graphite platform. Analytical curves with standard solutions containing $1 \%(\mathrm{v} / \mathrm{v})$ nitric acid (instrumental blank) were constructed.

\section{Results and Discussion}

Our initial purpose was the development of a methodology to measure zinc directly in coconut water samples utilizing PSA, without electrolyte addition or sample dilution. The respective signal would give us information on zinc not associated with organic molecules in solution. ${ }^{33}$ However, our experiments with coconut water sample in natura and even filtered (500, 200, 50 and $5 \mathrm{kDa}$ filters) have evinced the occurrence of electrode passivation, probably due to the strong adsorption of organic molecules on the mercury film electrode. Similar behavior was verified for copper at gold electrodes.

Therefore, the application of an ultrasound-assisted treatment was evaluated in order to unbind the zinc associated to organic compounds, such as proteins, carbohydrates, and lipids. The mixture of concentrated 
Table 2. Graphite furnace heating program for zinc and copper determination in coconut water

\begin{tabular}{|c|c|c|c|c|c|c|c|}
\hline \multirow[t]{2}{*}{ Step } & \multicolumn{3}{|c|}{ Zinc } & \multicolumn{3}{|c|}{ Copper } & \multirow{2}{*}{ 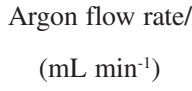 } \\
\hline & $\mathrm{T} /\left({ }^{\circ} \mathrm{C}\right)$ & Ramp/(s) & Hold/(s) & $\mathrm{T} /\left({ }^{\circ} \mathrm{C}\right)$ & Ramp/(s) & Hold/(s) & \\
\hline Drying I & 110 & 10 & 15 & 110 & 10 & 15 & 1000 \\
\hline Drying II & 130 & 2 & 10 & 130 & 2 & 10 & 1000 \\
\hline Pyrolysis I & 500 & 10 & 20 & 400 & 5 & 5 & 1000 \\
\hline Pyrolysis II & - & - & - & 1200 & 10 & 20 & 1000 \\
\hline Atomization & 2000 & 0 & 3 & 2300 & 0 & 3 & 0 \\
\hline Cleaning & 2400 & 1 & 4 & 2400 & 1 & 4 & 1000 \\
\hline
\end{tabular}

$\mathrm{HCl}$ and $\mathrm{H}_{2} \mathrm{O}_{2}$ was tested for the metal liberation by the complex formation with chlorine and partial decomposition of the organic compounds. Previous work showed the successful action of this mixture for metals extraction from lubricating oil. ${ }^{26}$

The boiling water bath had two functions: $(i)$ to improve the decomposition procedure (tightly closed vessels) and (ii) to eliminate the residual $\mathrm{H}_{2} \mathrm{O}_{2}$ (partially opened vessels).

When the vessels containing sample and oxidant mixture were submitted only to boiling water bath (without a previous sonication step), only part of zinc was liberated from organic matrix, corresponding approximately to $40 \%$ $(n=5)$ of the total zinc content. When the samples were sonicated before the boiling water bath treatment, the recovery of zinc was almost $100 \%$ and the concentration closer to the GFAAS results. On the other hand, when only the sonication step was applied, an elevated instability of the measurements was verified, mainly due to the formation of gas bubbles on the electrode surface, and the amount of zinc detected was situated in the 40-60\% range.

Different oxidant/sample volume ratios were evaluated for different exposure times in the ultrasonic bath. The zinc content was measured for three different volume ratios: $1,1.5$ and $2 \mathrm{~mL}$ of sample were added to 2, 1.5 and $1 \mathrm{~mL}$ of oxidant mixture, respectively. For 15 minutes of sonication followed by boiling water bath step, the optimized volume ratio was $1 \mathrm{~mL}$ of sample 2 $\mathrm{mL}$ of oxidant mixture. The efficiency verified for the other oxidant/sample volume ratios in this series of experiments was also elevated, superior to $85 \%(n=4)$ for all situations.

Otherwise, copper release from the sample matrix cannot be evaluated as was done for zinc due to the very low concentration of the metal in the different analyzed samples, which was lower than the limit of detection (LOD) obtained by GFAAS $\left(0.49 \mu \mathrm{g} \mathrm{L}^{-1}\right)$ and even lower than the obtained by the PSA method at gold electrode $\left(0.030 \mu \mathrm{g} \mathrm{L}^{-1}\right)$. As described in previous works, ${ }^{17,26,34}$ the addition of chloride ions in the electrolyte enhanced the sensitivity of copper when stripping electroanalytical techniques were applied at gold electrodes $\left(\mathrm{Cl}^{-}\right.$ions were sourced from the $\mathrm{HCl}$ used in the sample preparation). Additionally, the preconcentration step of 600 seconds (applying $0 \mathrm{mV}$ vs. $\mathrm{Ag} / \mathrm{AgCl})$ dramatically improved the LOD for copper at gold electrodes. The low concentration of copper in coconut water was previously verified in a recent work. ${ }^{10}$

Table 3 presents PSA and GFAAS total zinc determinations in four different samples and the statistical $t$-test applied to evaluate the proposed PSA method. The best conditions were observed when $1 \mathrm{~mL}$ of sample was added with $2 \mathrm{~mL}$ of the $1: 1(\mathrm{v} / \mathrm{v}) \mathrm{HCl}_{\text {conc }}$ and $\mathrm{H}_{2} \mathrm{O}_{2}$ in closed vessels and sonicated for 15 minutes, followed by treatment in boiling water for more 15 minutes. The optimized deposition potential was $-1.4 \mathrm{~V}$ (vs. $\mathrm{Ag} / \mathrm{AgCl}$ ) since at more negative potentials $\mathrm{H}^{+}$is significantly reduced, producing hydrogen gas on the electrode surface. Adopting these conditions, no electrode passivation was observed. Short deposition times were required for these determinations, once the concentration of zinc in the samples is relatively high. The zinc concentration in the coconut water samples was close to the values obtained previously (200-360 $\left.\mu \mathrm{g} \mathrm{L}^{-1}\right)$. ${ }^{9,10}$

In accordance with Table 3, standard deviations for PSA determinations of zinc are higher in average than the ones for GFAAS determinations. The standard addition

Table 3. Results of zinc concentration (mean \pm standard deviation) obtained by GFAAS and PSA in four different coconut water samples $(\mathrm{n}=3)$. $t$-test for individual samples $(95 \%$ confidence $)$

\begin{tabular}{lccc}
\hline \multicolumn{4}{c}{ Zinc concentration/ $\left(\mathrm{mg} \mathrm{L}^{-1}\right)$} \\
\hline Samples & PSA & GFAAS & $t$-test \\
1 & $492 \pm 38$ & $506 \pm 2$ & 0.64 \\
2 & $355 \pm 37$ & $356 \pm 54$ & 0.05 \\
$3^{*}$ & $298 \pm 13$ & $300 \pm 11$ & 0.27 \\
$4^{*}$ & $105 \pm 10$ & $114 \pm 6$ & 1.56 \\
\hline$*$ Commercialized bottled
\end{tabular}

* Commercialized bottled samples. 
method has to be applied for PSA since the sample matrix was not eliminated in the preparation step, and consequently higher standard deviations were produced. During the GFAAS determinations, the drying and pyrolysis steps were responsible to decompose the sample matrix prior the atomization. Therefore, GFAAS determinations were carried out by using a calibration curve with aqueous standard solutions. Except for sample 2 , low standard deviations were typically obtained for GFAAS analysis.

The statistical $t$-test (for $95 \%$ confidence, $t_{\text {table }}=4.30$ ) for independent samples shows good agreement between the results for zinc concentrations in the different samples (in all cases, $t_{\text {calculated }}$ was smaller than $t_{\text {table }}$ ).

The LOD for the proposed PSA method was $1.35 \mu \mathrm{g}$ $\mathrm{L}^{-1}$ applying $-1400 \mathrm{mV}$ ( $v s . \mathrm{Ag} / \mathrm{AgCl}$ ) for 45 seconds while the GFAAS method presented $0.64 \mu \mathrm{g} \mathrm{L}^{-1}$ as LOD. Since the zinc concentration in coconut water is typically very high, larger deposition times were not selected. Even though, the LOD can be improved extending the deposition step.

Repetitive signals, linear calibration curves and good reproducibility of analysis (RSD $<6 \%$ ) were obtained. A series of typical stripping potentiograms for the analysis of coconut water and the respective calibration curve are presented in Figure 1. The correlation coefficient is higher than 0.999 and the slope for this curve is $0.00386 \mathrm{~s} \mathrm{sg}^{-1} \mathrm{~L}$.

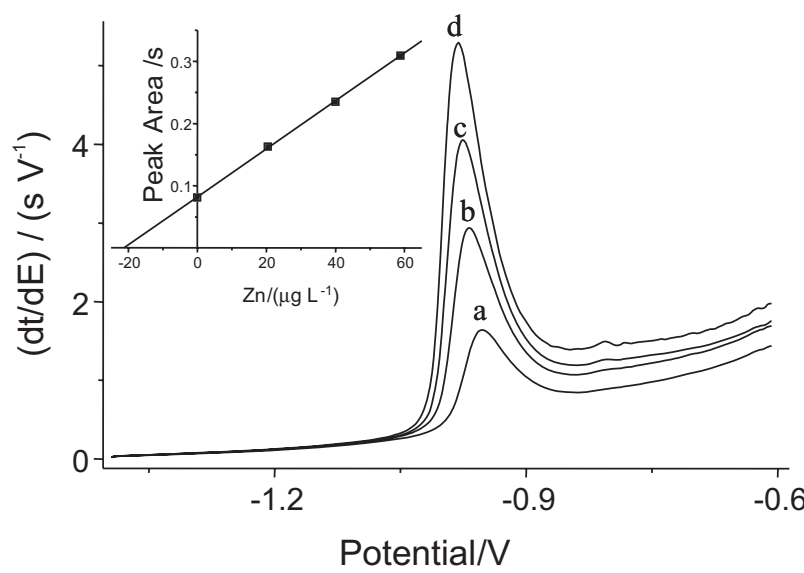

Figure 1. Stripping potentiograms for: (a) treated coconut water (sample number 4); (b-d) three additions of $30 \mu \mathrm{L}$ of $1 \mathrm{mg} \mathrm{L}^{-1}$ standard solution of zinc. Insert: Calibration curve of the potentiograms. PSA parameters are listed in Table 1.

Correlation coefficients were typically higher than 0.99 and the average slope was $0.0037 \pm 0.0002 \mathrm{~s} \mathrm{sg}^{-1} \mathrm{~L}$ for all the series of samples analyzed. The good agreement between the results obtained by GFAAS and the proposed PSA method indicates the potential application of stripping technique for the zinc determination in processed and unprocessed coconut water, after the ultrasound/heating procedure. Despite the inconvenient introduction of an additional step in the overall analytical method being a possible contamination source, the ultrasound/heating treatment was significant to perform an accurate zinc determination by PSA. The combination of low-cost equipments such as a potentiostat (especially for PSA) and an ultrasonic bath, which is often found at routine laboratories, is very promising to solve other analytical purposes. ${ }^{25,26,29}$

\section{Conclusions}

PSA was successfully applied for the total zinc determination in coconut water after sample ultrasoundassisted treatment in $1: 1(\mathrm{v} / \mathrm{v})$ concentrated $\mathrm{HCl}$ and $\mathrm{H}_{2} \mathrm{O}_{2}(30 \% \mathrm{~m} / \mathrm{v})$ mixture, followed by heating treatment. The proposed method was validated by the GFAAS determinations for commercialized bottled samples and coconut water directly extracted from the fruit. The complex composition of coconut water is likely to interfere on PSA measurements when the sample was not pretreated. Organic molecules present in coconut water may adsorb on the mercury film electrode during PSA measurements, which did not allow accurate analytical zinc detection in untreated (in natura) coconut water samples. Similar evaluation was not possible to carry out for copper due to its very low concentrations.

Comparing GFAAS with electroanalytical stripping techniques, the first one is more adequate for accurate trace metal determinations since no prior sample preparation is necessary. Inductively coupled plasma optic emission spectrometry (ICP OES) can be very interesting for the simultaneous determination of many elements, but not at ultra-trace concentration level. As sensitive as GFAAS, stripping techniques offer lower-cost analyses and equipments more accessible to different laboratories. In addition, the ease of miniaturization and the possibility of construct disposable devices to be utilized for individual analysis are other attractive aspects of PSA.

\section{Acknowledgments}

Authors are grateful to Conselho Nacional de Desenvolvimento Científico e Tecnológico (CNPq) and Fundação de Amparo à Pesquisa do Estado de São Paulo (FAPESP) for financial support. Rodrigo A. A. Munoz (01/ 11271-8) and Rita C. Siloto (03/02954-0) thank to FAPESP for fellowship. Lúcio Angnes and Pedro V. Oliveira acknowledge to CNPq for the fellowships. This work was supported by RENAMI, IM ${ }^{2} \mathrm{C}$ and CTPetro grants. 


\section{References}

1. Campos, C.F.; Souza, P.E.A.; Coelho, J.V.; Gloria, M.B.A.; J. Food Process. Preserv. 1996, 20, 487.

2. Andrade, E.R.; Amorim, C.A.; Matos, M.H.T.; Rodrigues, A.P.R.; Silva, J.R.V.; Dode, M.A.N.; Figueiredo, J.R.; Small Rum. Res. 2002, 43, 235.

3. Petroianu, G.A.; Kosanovic, M.; Shehatta, I.S.; Mahgoub, B.; Saleh, A.; Maleck, W.H.; J. Trace Elem. Exp. Med. 2004, 17, 273.

4. Khan, M.N.; Muti-Ur-Rehman; Khan, K.W.; Pakistan J. Botany 2003, 35, 925.

5. Jackson, J.C.; Gordon, A.; Wizzard, G.; McCook, K.; Rolle, R.; J. Sci. Food Agric. 2004, 84, 1049.

6. Santoso, U.; Kubo, K.; Ota, T.; Tadokoro, T.; Mackawa, A.; Food Chem. 1996, 7, 299.

7. Ge, L.Y.; Yong, J.W.H.; Tan, S.N.; Yang, X.H.; Ong, E.S.; J. Chromatogr. A 2004, 1048, 119.

8. Brito, N.M.; Navickiene, S.; Polese, L.; Jardim, E.F.G.; Abakerli, R.B.; Ribeiro, M.L.; J. Chromatogr. A 2002, 957, 201.

9. De Sousa, R.A.; Silva, J.C.J.; Baccan, N.; Cadore, S.; J. Food Compos. Anal. 2005, 18, 399.

10. De Sousa, R.A.; Baccan, N.; Cadore, S.; J. Braz. Chem. Soc. 2005, 16, 540.

11. Aleixo, P.C.; Nóbrega, J.A.; Junior, D.S.; Muller, R.C.S.; Quim. Nova 2000, 23, 310.

12. Oliveira, A.P.; Gomes-Neto, J.A.; Nóbrega, J.A.; Correia, P.R.M.; Oliveira, P.V.; Food Chem. 2005, 93, 355.

13. Richter, E.M.; De Jesus, D.P.; Munoz, R.A.A.; Do Lago, C.L.; Angnes, L.; J. Braz. Chem. Soc. 2005, 16, 1134.

14. Da Silva, I.S.; Richter, E.M.; Do Lago, C.L.; Gutz, I.G.R.; Tanaka, A.A.; Angnes, L.; Talanta 2005, 67, 651.

15. Soares, H.M.V.M.; Vasconcelos, M.T.S.D.; Talanta 1995, 42, 621.

16. Chow, C.W.K.; Kolev, S.D.; Davey, D.E.; Mulcahy, D.E.; Anal. Chim. Acta 1996, 330, 79.
17. Munoz, R.A.A.; Angnes, L.; Microchem. J. 2004, 77, 157.

18. Munoz, R.A.A.; Silva, C.S.; Correia, P.R.M.; Oliveira, P.V.; Angnes, L.; Microchim. Acta 2005, 149, 199.

19. Jagner, D.; Josefson, M.; Westerlund, S.; Aren, K.; Anal. Chem. 1981, 53, 1406.

20. Wang, J.; Tian, B.; Wang, J.; Lu, J.; Olden, C.; Yarnitzky, C.; Olsen, K.; Hammerstrom, D.; Benett, W.; Anal. Chim. Acta 1999, 385, 429.

21. Marin, A.; López-González, A.; Barbas, C.; Anal. Chim. Acta 2001, 442, 305.

22. Al-Merey, R.; Al-Masri, M.S.; Bozou, R.; Anal. Chim. Acta 2002, 452, 143.

23. Ashley, K.; Andrews, R.N.; Cavazos, L.; Demange, M.; J. Anal. Atom. Spectrom. 2001, 16, 1147.

24. Elik, A.; Talanta 2005, 66, 882.

25. Ashley, K.; Electroanalysis 1995, 7, 1189.

26. Munoz, R.A.A.; Oliveira, P.V.; Angnes L.; Talanta 2006, 68, 850 .

27. Nascentes, C.C.; Korn, M.; Arruda, M.A.Z.; Microchem. J. 2001, 69, 37.

28. Liva, M.; Muñoz-Olivas, R.; Câmara, C.; Talanta 2000, 51, 381.

29. Zakharova, E.A.; Deryabina, V.I.; Slepchenko, G.B.; J. Anal. Chem. 2005, 60, 503.

30. El Azouzi, A.; Cervera, M.L.; de la Guardia, M.; J. Anal. Atom. Spectrom. 1998, 13, 533.

31. Pedrotti, J.J.; Angnes, L.; Gutz, I.G.R.; Electroanalysis 1996, $8,673$.

32. Angnes, L.; Richter,E.M.; Augelli, M.A.; Kume, G.H.; Anal. Chem. 2000, 72, 5503.

33. Florence, T.M.; Analyst 1986, 111, 489.

34. Richter, E.M.; Augelli, M.A.; Magarotto, S.; Angnes, L.; Electroanalysis 2001, 13, 760.

Received: January 26, 2006

Web Release Date: March 30, 2007

FAPESP helped in meeting the publication costs of this article. 